\title{
Clean and Feasible Utilization of High Silica Fluorspar Powder via Reverse Flotation: A Pilot Study
}

\author{
Chenhu Zhang ${ }^{1,2}$, Jiande Gao ${ }^{2,3}$, Yuehua Hu ${ }^{2, *}$, Wei Sun ${ }^{2}$, Fei Lv ${ }^{2}$ and Zhenjun Liu ${ }^{2}$ \\ 1 School of Chemistry and Material engineering, Liupanshui Normal University, Liupanshui 553004, China; \\ lupin626@163.com \\ 2 School of Mineral Processing and Bioengineering, Central South University, Changsha 410083, China; \\ fyjgjd@163.com (J.G.); sunmenghu@csu.edu.cn (W.S.); lvfei2012@csu.edu.cn (F.L.); louisliu@163.com (Z.L.) \\ 3 College of Chemistry and Chemical Engineering, Central South University, Changsha 410083, China \\ * Correspondence: huyuehuacsu@126.com
}

\section{check for}

updates

Citation: Zhang, C.; Gao, J.; Hu, Y.; Sun, W.; Lv, F.; Liu, Z. Clean and Feasible Utilization of High Silica Fluorspar Powder via Reverse Flotation: A Pilot Study. Minerals 2021, 11, 555. https://doi.org/ $10.3390 / \min 11060555$

Academic Editors: Kirsten

Claire Corin, Wenjihao Hu,

Peipei Wang, Ljudmilla Bokányi and Zhiyong Gao

Received: 16 April 2021

Accepted: 20 May 2021

Published: 24 May 2021

Publisher's Note: MDPI stays neutral with regard to jurisdictional claims in published maps and institutional affiliations.

Copyright: (c) 2021 by the authors. Licensee MDPI, Basel, Switzerland. This article is an open access article distributed under the terms and conditions of the Creative Commons Attribution (CC BY) license (https:/ / creativecommons.org/licenses/by/ $4.0 /)$.

\begin{abstract}
Fluorite is a nonrenewable mineral used to produce anhydrous hydrofluoric acid (AHF) and aluminum fluoride. The demand for low-grade fluorite powder $\left(\mathrm{CaF}_{2}<97 \%\right)$ has fallen sharply owing to the current market conditions. Therefore, a large number of fluorite concentrates have been improved by acid leaching. While this approach can efficiently remove $\mathrm{CaCO}_{3}$ from fluorite concentrate, the $\mathrm{SiO}_{2}$ content, which significantly affects AHF consumption during the production of HF or aluminum fluoride, cannot be completely removed. To solve this problem, in this study, we used reverse flotation before leaching the fluorite concentrates. Subsequently, the feasibility of reverse flotation desilication was determined. The obtained results of the ZP (zeta potential) measurements, solution chemistry analysis, FTIR (Fourier transform infrared spectroscopy) analysis, and micro-flotation tests indicated that employing dodecylamine as the collector and citric acid as the depressor could effectively separate sericite from fluorite. The batch flotation experiment and the pilot test were conducted in Chenzhou (Hunan, China) followed by their operation in Xinyuan Mining Co. Ltd., which produces monolithic fluorite ore on the large scale in Asia. Notably, we found that the contents of both $\mathrm{SiO}_{2}$ and $\mathrm{Al}_{2} \mathrm{O}_{3}$ were from $2.82 \%, 1.17 \%$ reduced to $1.28 \%, 0.74 \%$ in the batch flotation experiment. The results of the pilot test showed that the new reverse flotation + leaching technology could dramatically reduce the potential environmental impact and costs, thereby significantly improving the economic benefits by satisfying the requirements of the market.
\end{abstract}

Keywords: fluorite; desilication; reverse flotation; leaching

\section{Introduction}

Fluorite $\left(\mathrm{CaF}_{2}\right)$ is a non-renewable mineral and is employed as a flux agent in steelmaking and hydrofluoric acid production [1,2]. In China, the mineral is derived mainly from naturally occurring fluorite minerals and tailings of tungsten, and there are a few notable differences between both the production processes. Moreover, the ultimate objective of every Chinese company is to produce high-grade products $\left(\mathrm{CaF}_{2} \geq 97 \%, \mathrm{SiO}_{2}<1 \%\right)$.

In the past, the fluorite concentrate's quality index was usually $\mathrm{CaF}_{2} \geq 97 \%$. However, although the fluorite production was efficient, the side effects of resource exploitation in China were becoming increasingly apparent, and it was difficult to maintain a steady production of high-grade fluorite, which contained more impurities than before. The two major impurities found in fluorite concentrates are carbonate $\left(\mathrm{CaCO}_{3}\right)$ and silicate $\left(\mathrm{SiO}_{2}\right)$. Several studies reported that all commercial fluorite production processes used froth flotation to remove the impurities [3-7]. Furthermore, this method was widely employed to remove gangue minerals from fluorite concentrations to further improve the fluorite grade [8-11].

The Jiepailing fluorite mine is the single largest fluorite deposit in China, and has the largest ore of monolithic fluorite in Asia, and reserves 26.21 million tons of $\mathrm{CaF}_{2}$ mineral. 
In our previous study, the use of a two-stage depressed technology in the Jiepailing fluorite mine proved to be successful [12]. Thus far, a two-stage depressed process comprising one roughing and six cleaning procedures has been used for the processing of fluorite minerals. Subsequently, concentrates containing 93\% fluorite, $2.5 \%$ calcite, and 3.5\% sericite were obtained. Nonetheless, there is a lot of uncertainty regarding the current market and the cost of fluorite powders $\left(93 \% \leq \mathrm{CaF}_{2} \leq 97 \%\right)$. This is primarily because $\mathrm{CaCO}_{3}$ in the fluorite concentrates consumes sulfuric acid $\left(\mathrm{H}_{2} \mathrm{SO}_{4}\right)$ and is also associated with the generation of heat energy and waste volume during the furnace reactions in the acidulation of fluorite concentrate. This creates a burden on anhydrous hydrofluoric acid (AHF) manufacturers because of the increased production costs. In such cases, leaching is the easiest solution. As shown in Figure 1, the fluorite concentrate is leached by waste hydrochloric acid (from a downstream chemical plant) after flotation.

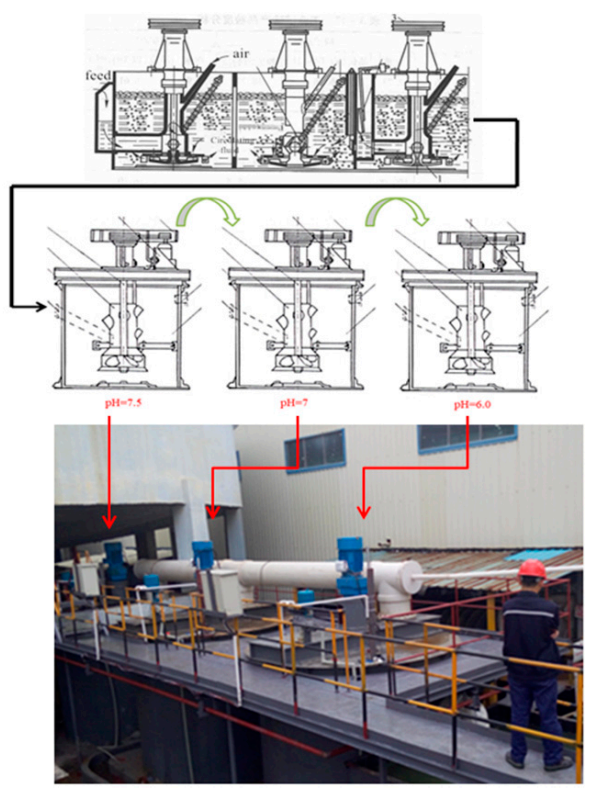

Figure 1. Acid leaching process of fluorite minerals in the Xinyuan dressing plant.

Through this process, the calcite present in the fluorite concentrate was removed completely, but the $\mathrm{CaF}_{2}$ content increased to $\sim 96 \%$ only and the remaining impurities could not be removed by this method. Moreover, sericite $\left(\mathrm{SiO}_{2}\right)$ is a more important impurity than $\mathrm{CaCO}_{3}$ because it affects $\mathrm{H}_{2} \mathrm{SO}_{4}$ consumption during hydrofluoric acid (HF) or aluminum fluoride production. A number of side effects occur during the preparation owing to the hydrogen fluoride gas present in the reactor: $4 \mathrm{HF}(\mathrm{g})+\mathrm{SiO}_{2}(\mathrm{~s})=2 \mathrm{H}_{2} \mathrm{O}(\mathrm{g})+\mathrm{SiF}_{4}(\mathrm{~g})$. Copious amounts of raw materials could be lost during production because of the high $\mathrm{SiO}_{2}$ content. Furthermore, against the background of this unprecedented situation caused by the pandemic, we need to find an effective method to desilicate fluorite concentrates before leaching.

Currently, during the direct flotation process, it is difficult to remove the silica completely via entrainment and the dissolved $\mathrm{Ca}$ ion might activate the sericite surface, as observed in our previous studies. In addition, further flotation cleaning was found to be ineffective. Therefore, we decided to use reverse flotation because it can be successful in cases where the gangue contains silicates (quartz or mica) and is floated with a collector of amine-type, while the valuable minerals are hydrophilic and are enriched in the underflow fraction [13-15]. This method was also reported to be the most widely used technology for the desilicification of various important minerals, i.e., iron ore and magnesite ore [16-18]. Several studies have been focusing on various amines and their derivatives that can be employed as cationic collectors in reverse flotation. Dodecylamine (DDA) is exceptionally effective as a collector of silicate minerals [19-22]. 
Conversely, fluorite depressants can efficiently enhance the flotation separation of sericite from fluorite. Liu and Zhang observed that citric acid (CA) might successfully eradicate $\mathrm{Ca}^{2+}$ ions from the chalcopyrite surface, thereby associated with the increase in the selective flotation separation between galena and chalcopyrite through the use of dextrin $[23,24]$. Additionally, Gao et al. and Gan et al. reported that CA exerts sufficient depressive effects on the oleate flotation of fluorite because of its robust chelating capacity with $\mathrm{Mg}^{2+}$ or $\mathrm{Ca}^{2+}[25,26]$. Thus, these studies provided us with valuable insights into our analysis.

Consequently, it is worthwhile to develop a new method to achieve desilication and purification of fluorite concentrate before acid leaching. Although we have previously formulated an efficient two-stage depressing process for mineral processing, this study addresses the need for an efficient chemical scheme for improving the separation of sericite minerals in fluorite flotation. Fundamental analyses, such as micro-flotation, batch flotation, solution chemistry analysis, ZP measurements, and FTIR were conducted for the detailed information regarding the mechanism. This pilot study was carried out in the Xinyuan fluorite dressing plant and can potentially solve several long-standing complications regarding the shortage of high-quality fluorite concentrates.

\section{Materials and Methods}

We obtained pure fluorite and sericite samples from Hunan, China. The spectra of X-ray diffraction depicted in Figure 2 confirm the $98.41 \%$ and $91 \%$ purity of the fluorite and sericite samples, respectively. Grinding of the samples was performed using an agate mortar.
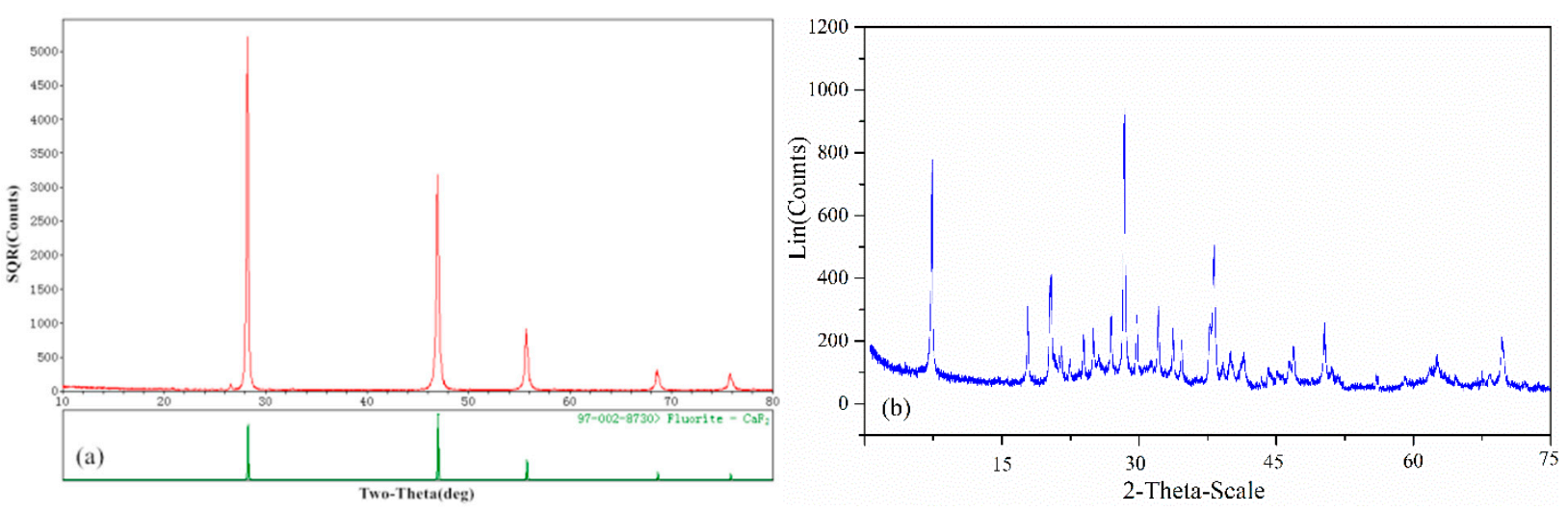

Figure 2. Spectra of X-ray diffraction for (a) fluorite and (b) sericite samples used for the flotation tests.

A micro-floatation test was conducted with the particle size of the fraction range from $+37-74 \mu \mathrm{m}$. Further grinding of the samples was performed to obtain $-5 \mu \mathrm{m}$ size, and they were then used for ZP measurements and FTIR.

The fluorite concentrate in the real ore flotation test was a flotation separation concentrate supplied by Hunan Xinyuan Mineral Company. The samples consisted of $92.87 \%$ $\mathrm{CaF}_{2}$ and $2.82 \% \mathrm{SiO}_{2}$.

The following suppliers were contacted for the chemically pure reagents: citric acid $\left(\mathrm{H}_{2} \mathrm{C}_{2} \mathrm{O}_{4}\right)$ from Aladdin Biological Technology Ltd., Shanghai, China, and DDA $\left(\mathrm{C}_{12} \mathrm{H}_{27} \mathrm{~N}\right)$ from Baisaiqin Chemical Technology Co., Ltd., Shanghai, China. Diluted solutions ( $0.1 \%)$ of $\mathrm{HCl}$ or $\mathrm{NaOH}$ were used for adjusting the $\mathrm{pH}$.

Deionized water (DI, $18 \mathrm{~m} \Omega \cdot \mathrm{cm}$ ) was used for micro-flotation and test experiments.

\subsection{Micro-Flotation Experiments}

A hitch-groove flotation cell (40-mL), kept in a mechanically agitated flotation machine, was used to conduct the micro-flotation experiment. Particles $(2.0 \mathrm{~g})$ of the pure mineral were kept in a Plexiglas cell containing DI water $(35 \mathrm{~mL})$. For $2 \mathrm{~min}$ the $\mathrm{pH}$ of 
the resulting suspension was adjusted via the addition of $\mathrm{NaOH}$ or $\mathrm{HCl}$, followed by depressant incorporation. Post 3 min conditioning of the suspension with the depressant, incorporation of the collector was made and provided $3 \mathrm{~min}$ agitation for the suspension.

For the flotation of the individual mineral, we collected and filtered the floated and unfloated particles and allowed them to dry. Individual micro-flotation tests were performed thrice and their average values were reported as the final result.

\subsection{Measurement of Zeta Potential}

Measurement for the $\mathrm{ZP}$ was carried out at $20{ }^{\circ} \mathrm{C}$ via the $\mathrm{ZP}$ analyzer (Zetasizer, Malvern, UK). The mineral suspensions with $40 \mathrm{~mL}$ of $\mathrm{KCl}(0.01 \mathrm{~mol} / \mathrm{L})$ and $0.016 \mathrm{~g}$ solids were prepared at a given collector concentration and $\mathrm{pH}$ and were used as the background electrolyte. The supernatant liquor obtained after a settling period of $5 \mathrm{~min}$ was used to measure the ZP measurement.

\subsection{FTIR Spectral Analysis}

We recorded the FTIR spectra of the samples on a Bruker Alpha FTIR spectrometer (Thermo, Waltham, MA, USA) at $\sim 25^{\circ} \mathrm{C}$. Analysis of the samples was conducted by forming a $\mathrm{KBr}$ disc and scanned over a range of 400 to $4000 \mathrm{~cm}^{-1}$. Analysis procedures for the powder samples were as follows: the mineral powder $(0.1 \mathrm{~g})$ addition to the solution of the desired volume $(25 \mathrm{~mL})$ was carried out, followed by ultrasonication and stirring for $3 \mathrm{~min}$ each, and then treated for $6 \mathrm{~min}$. After filtration, the solid material was obtained by using a vacuum drying method for the subsequent FTIR reflection spectroscopic measurements. The infrared spectrum of the untreated mineral was considered as the reference.

\subsection{Batch Flotation Experiment}

Fluorite concentrate ores were procured from Xinyuan Mining Co. Ltd. (Chenzhou, China) and were then divided into two portions. One portion was separated from the origin reagents using ultrasonic cleaning equipment, and the other was left unchanged. In an XFD-63 flotation cell $(0.5 \mathrm{~L})$ at a $\mathrm{pH}$ of approximately 6 , the pulp was conditioned to solids (30\%) with the depressant and collector. Fluorite concentrate (100 g) was used for flotation tests with $1700 \mathrm{r} / \mathrm{min}$ flotation impeller speed. The tests of ore flotation were carried out according to the illustration described in Figure 3. Three replicates of the experiments were conducted and their mean values were regarded as the final results.

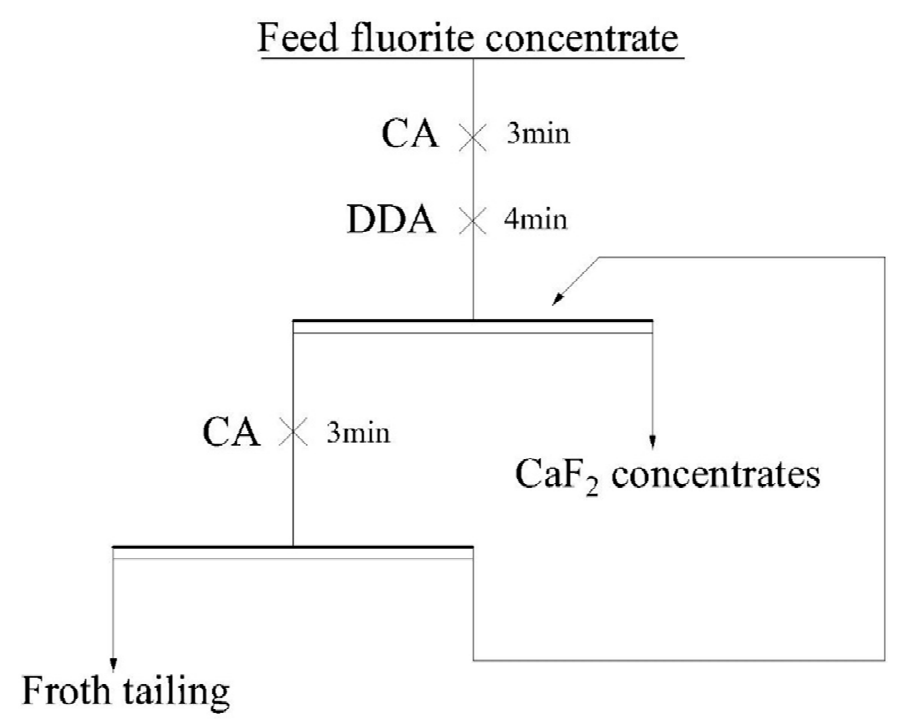

Figure 3. Flowsheet of the flotation tests. 


\subsection{Pilot Test}

The pilot test was performed in the Xinyuan factory, and the scale of the test was $25 \mathrm{t} /$ day. The tests for the reverse flotation process and the direct leaching process were conducted with the selected collector and depressant. The results were then compared to obtain a detailed waste acid consumption analysis and the accurate removal rate of $\mathrm{SiO}_{2}$. Comparison diagram of pilot process is shown in Figure 4.

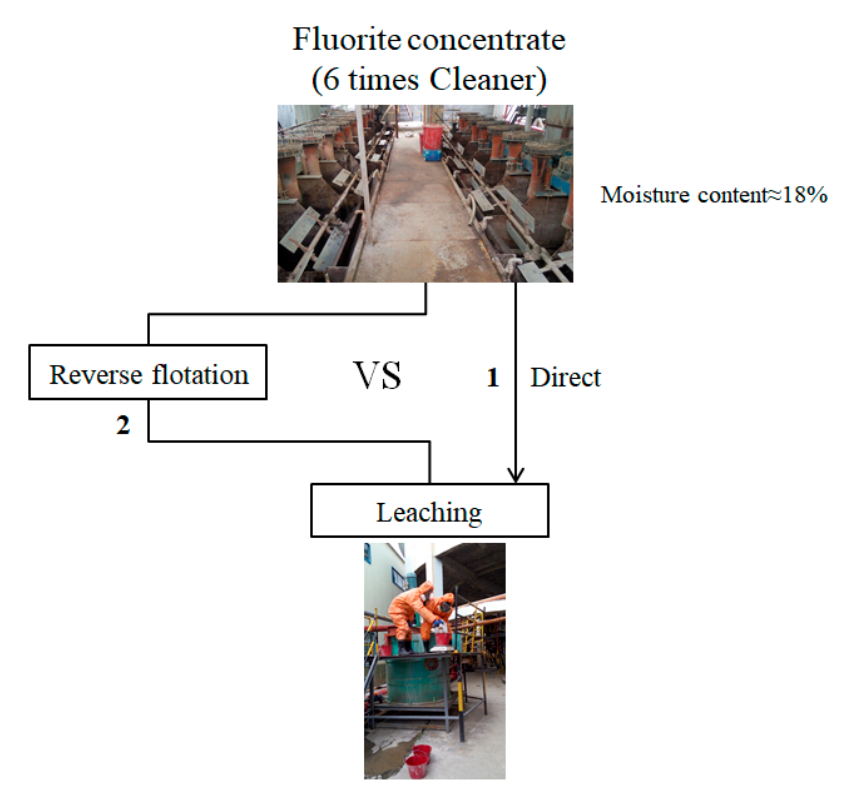

Figure 4. Comparison flowsheet of the pilot test (1. Direct leaching; 2. Reverse flotation before leaching).

\section{Results and Discussion}

\subsection{Micro-Flotation of Pure Minerals}

Figure 5 depicts the flotation recoveries of sericite and fluorite as a function of $\mathrm{pH}$ of $1 \times 10^{-4} \mathrm{~mol} / \mathrm{L}$ DDA. Results show that sericite recovery is slightly elevated with the elevation in $\mathrm{pH}$ value. When DDA was used, the recovery of sericite was maintained above $60 \%$ in $\mathrm{pH}$ ranging from 2 to 3 . Contrarily, the recovery of fluorite varied widely from 4.69 to $5.86 \%$ in a similar $\mathrm{pH}$ range, and a dramatic increase in fluorite recovery was observed at $\mathrm{pH}>3$. Therefore, a significant difference was observed between the recoveries of the two minerals in the strongly acidic $\mathrm{pH}$ range. At $\mathrm{pH} \mathrm{2,50.65 \%} \mathrm{of} \mathrm{sericite} \mathrm{was} \mathrm{recovered,}$ which was sufficient for the flotation separation of sericite from fluorite, i.e., sericite could be selectively floated from fluorite with DDA as the collector at $\mathrm{pH} 2$. For the following test, the $\mathrm{pH}$ was kept constant at $\mathrm{pH} 2$.

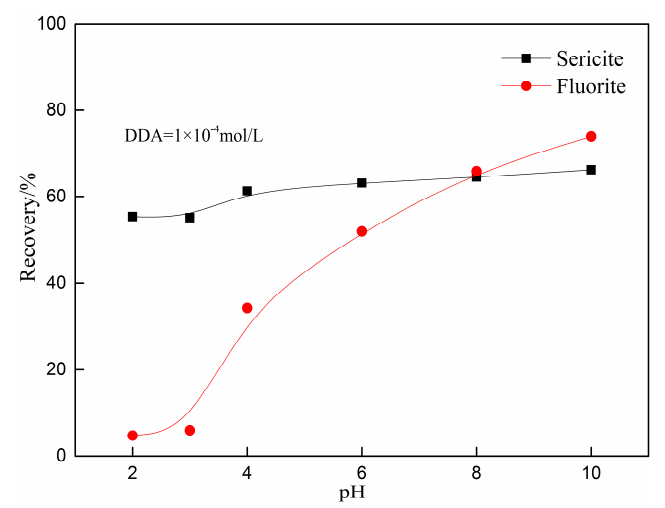

Figure 5. Depicted the recovery of sericite and fluorite as a function of $\mathrm{pH}$ via DDA as a collector (concentration $=1 \times 10^{-4} \mathrm{~mol} / \mathrm{L}$ ). 
Figure 6 demonstrates the sericite and fluorite recovery as a function of DDA dosage at $\mathrm{pH} 2$ and the picture showing that the sericite recovery slowly increased with an elevation in the concentration of DDA. The selective flotation of sericite and fluorite can be achieved with a DDA concentration higher than $20 \times 10^{-5} \mathrm{~mol} / \mathrm{L}$. Though, the sericite recovery was only $\sim 69 \%$. Moreover, owing to its hydrophilic property, hardly $31 \%$ of the sericite was removed from the pulp. Nevertheless, the recovery of fluorite increased rapidly when greater than $20 \times 10^{-5} \mathrm{~mol} / \mathrm{L}$ of concentration of DDA was there. This was because entrainment still exists because froth collapse from high concentration DDA is a long time. Although the result of the separation was satisfactory, it was difficult to operate the production process in a highly acidic environment $(\mathrm{pH}=2)$ because of the potentially high cost and equipment corrosion. Thus, CA was used to depress fluorite, which hindered the adsorption with DDA. Figure 7 displays sericite and fluorite recovery as a function of CA dosage at $\mathrm{pH} 7$.

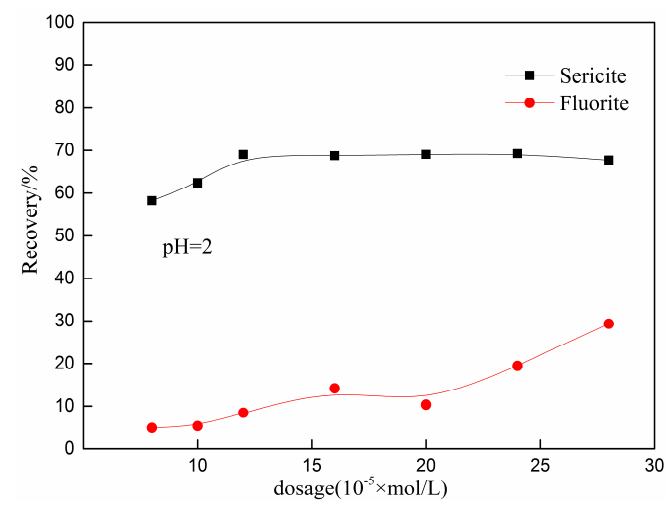

Figure 6. Recovery of sericite and fluorite as a function of DDA dosage at $\mathrm{pH} 2$.

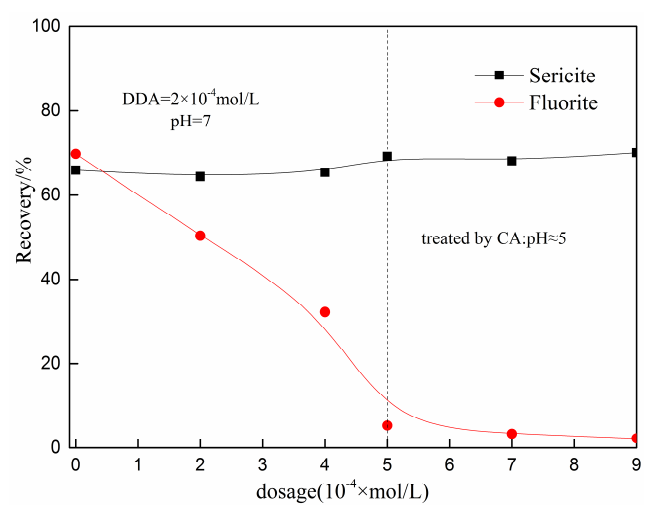

Figure 7. Recovery of sericite and fluorite as a function of CA dosage at $\mathrm{pH} 7$.

Figure 7 reveals that the recovery of sericite was stable under weak acid or neutral conditions. Almost the same recovery was observed in the presence of CA as observed in its absence, indicating the weak depressive effect of CA on sericite flotation. Nevertheless, the recovery of fluorite sharply decreased when the CA concentration increased. When the CA dosage was $5 \times 10^{-4} \mathrm{~mol} / \mathrm{L}$, the minimum fluorite recovery reached $4.83 \%$. Based on these results, it was conjectured that CA could effectively depress fluorite at $\mathrm{pH} 7$.

$\mathrm{CA}$ is a widely available trimacinic organic acid and could effectively adjust the value of pulp $\mathrm{pH}$. The $\mathrm{pH}$ of the pulp was approximately 5 , which was increased by the CA dosage $\left(5 \times 10^{-4} \mathrm{~mol} / \mathrm{L}\right)$ as presented in Figure 7 . In addition, the $\mathrm{pH}$ value of the solution was found to play the most imperative role in the flotation process (Figure 5). To determine the impact of depressing by $\mathrm{CA}$ in the flotation process, Figure 8 shows the recovery of sericite and fluorite with or without CA as a function of DDA dosage. 


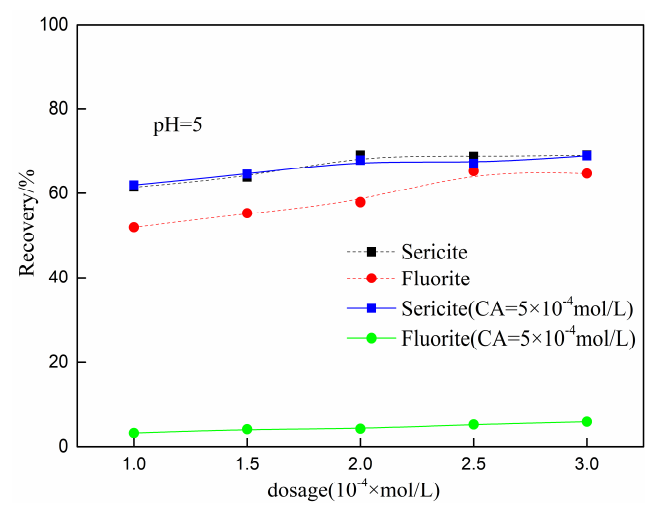

Figure 8. Recovery of sericite and fluorite both in the presence and absence of CA as a function of DDA dosage.

The obtained results in Figure 8 showed the satisfactory separation of sericite and fluorite by DDA in the presence of $\mathrm{CA}$ at a neutral $\mathrm{pH}$, but high dosages of CA affected the $\mathrm{pH}$, which can be elucidated with a comparison. In this test, the effect of DDA concentration was investigated in the absence and presence of $\mathrm{CA}$ at $\mathrm{pH} 5$.

Furthermore, when the DDA concentration was $2 \times 10^{-4} \mathrm{~mol} / \mathrm{L}$ at pH 5 , the floatability of the fluorite treated with CA was far lower than that of the untreated fluorite. The difference in floatability between the two conditions was approximately $55 \%$ when the DDA concentration was $3 \times 10^{-4} \mathrm{~mol} / \mathrm{L}$. This result indicated that the fluorite surface pretreatment, which reduced the $\mathrm{pH}$ prior to DDA addition, was beneficial to the depressing behavior of fluorite. This finding could be ascribed to the decreasing of the $\mathrm{pH}$ level in the pulp because of the acidity of CA. However, the main reason is the decrease in the DDA amount adsorbed onto the fluorite surface treated with CA. It could be concluded that CA not only preserved the $\mathrm{pH}$ value of the pulp for the best flotation conditions for sericite but also effectively depressed the fluorite.

\subsection{Zeta Potential (ZP)}

To investigate the $\mathrm{pH}$ effect on the fluorite and sericite $\mathrm{ZP}$ in the presence of the collector, electrokinetic potentials were measured with CA (Figure 9). In the $\mathrm{pH}$ range of 2 to 11 , the pure sericite minerals were always negatively charged, this is in a consistent with the results of the earlier study [27]. In the absence of reagents, fluorite had an isoelectric point (IEP) at $\mathrm{pH} 7.8$, which was also in agreement with existing studies [28].
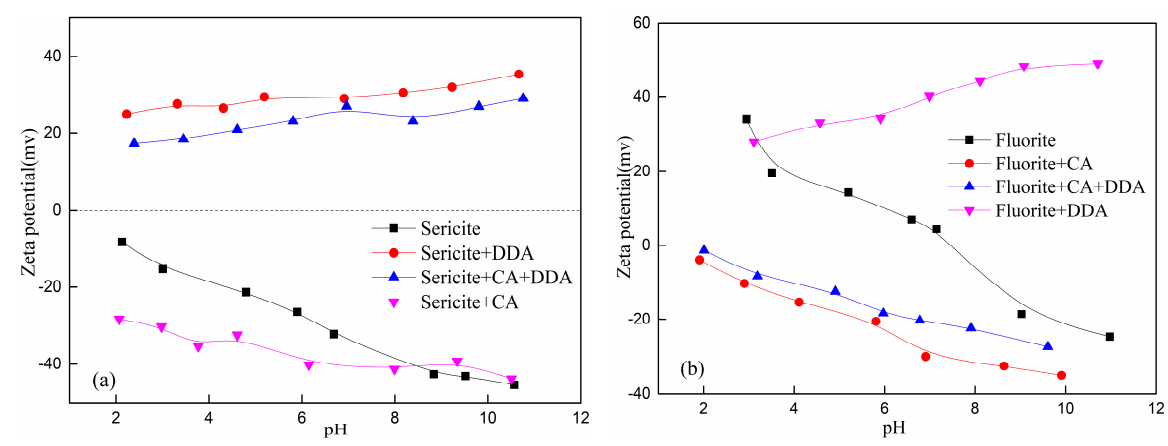

Figure 9. $\mathrm{ZP}$ of (a) sericite and (b) fluorite as a function of $\mathrm{pH}$ in various conditions.

As seen in Figure 9a, when the $\mathrm{pH}$ was in the range 2-11, the $\mathrm{ZP}$ of sericite changed from negative to positive in the presence of DDA. This indicated that a high level of DDA amount has been absorbed on the sericite surface. Additionally, upon the addition of depressant CA, the ZP decreased by approximately $10 \mathrm{mV}$ at the IEP ZP of sericite. This implied the slight absorption of CA on the negatively charged sericite surface and that the interaction between CA and the negatively charged sericite was weak. The depressant 
$\mathrm{CA}$ and the collector DDA incorporation increased the $\mathrm{ZP}$ of sericite by $35 \mathrm{mV}$, which suggested a strong electrostatic interaction of positively charged DDA with the negatively charged surface of sericite. The sericite $\mathrm{ZP}$ results in the presence of reagents also indicated that the quite stronger adsorption of DDA on the sericite surface than that of CA. Therefore, CA had little influence on the adsorption on the sericite surface. This is in good agreement with the results of the flotation depicted in Figure 6.

As shown in Figure 9b, a positively charged fluorite surface was observed at $\mathrm{pH}<7.8$ while it was negatively charged at $\mathrm{pH}>7.8$. After the addition of DDA to the pulp suspension, the $\mathrm{ZP}$ in the entire $\mathrm{pH}$ range increased, and rose more quickly at $\mathrm{pH}>7.8$, i.e., the $\mathrm{ZP}$ increased negatively, indicating that the interaction between DDA and fluorite surfaces gradually strengthened with increasing $\mathrm{pH}$.

Additionally, depressant CA incorporation alters the fluorite ZP significantly, as it was decreased by an average of $25 \mathrm{mV}$ during flotation, suggesting the strong depressant CA adsorption onto the fluorite surface. Unlike sericite, when both the collector DDA and the depressant CA were present, the fluorite ZP remained negative and only a slight increase than that in the presence of $\mathrm{CA}$ alone was observed in the $\mathrm{pH}$ range 2-11. This implied that the DDA adsorption on the surface of fluorite might be increasingly hindered by the presence of CA.

\subsection{Solution Chemistry Analysis}

The analysis of the solution chemistry of flotation is an effective way to examine the surface characteristics of the minerals and the reagents in the process of mineral flotation [29]. The solution chemistry equilibria of DDA are given as,

$$
\begin{gathered}
\mathrm{RNH}_{2(\mathrm{~s})}=\mathrm{RNH}_{2(\mathrm{aq})} \mathrm{S}=10^{-4.70} \\
\mathrm{RNH}_{3}{ }^{+}=\mathrm{RNH}_{2(\mathrm{aq})}+\mathrm{H}^{+} \mathrm{K}_{\mathrm{a}}=10^{-10.63} \\
2 \mathrm{RNH}_{3}{ }^{+}=\left(\mathrm{RNH}_{3}{ }^{2+}\right)_{2}^{2+} \mathrm{K}_{\mathrm{d}}=10^{2.08} \\
\mathrm{RNH}_{3}{ }^{+}+\mathrm{RNH}_{2(\mathrm{aq})}=\left[\mathrm{RNH}_{3}{ }^{+} \cdot \mathrm{RNH}_{2(\mathrm{aq})}\right] \mathrm{K}_{\mathrm{im}}=10^{3.12}
\end{gathered}
$$

The solution chemistry equilibria of CA are as follows:

$$
\begin{gathered}
\mathrm{H}_{3} \mathrm{Cit}=\mathrm{H}_{2} \mathrm{Cit}^{-}+\mathrm{H}^{+} \mathrm{K}_{\mathrm{a} 1}=10^{-3.13} \\
\mathrm{H}_{2} \mathrm{Cit}^{-}=\mathrm{HCit}^{2-}+\mathrm{H}^{+} \mathrm{K}_{\mathrm{a} 2}=10^{-4.76} \\
\mathrm{HCit}^{2-}=\mathrm{Cit}^{3-}+\mathrm{H}^{+} \mathrm{K}_{\mathrm{a} 3}=10^{-6.4} \\
\mathrm{Cit}^{3-}=\mathrm{Cit}^{4-}+\mathrm{H}^{+} \mathrm{K}_{\mathrm{a} 4}=10^{-11.6}
\end{gathered}
$$

Based on the above formulas, at DDA concentration $\left(\mathrm{C}_{\mathrm{DDA}}\right)=2 \times 10^{-4} \mathrm{~mol} / \mathrm{L}$, Figures 10 and 11 demonstrate the component distributions of DDA and CA, respectively, as a function of $\mathrm{pH}$.

Figure 10 indicated the precipitation of neutral $\mathrm{RNH}_{2}$ molecule at $\mathrm{pH} 10.04$, and its ionic forms $\left(\mathrm{RNH}_{3}\right)_{2}{ }^{2+}$ and $\mathrm{RNH}_{3}{ }^{+}$dominated in a $\mathrm{pH}$ range of 2.0-9.5. The maximum ion-molecular complex was observed at $\mathrm{pH}$ 9.85. Moreover, the sericite surface was always negative because the $\mathrm{pH}$ was less than 10 . The primary species of the collector are $\mathrm{RNH}_{2} \cdot \mathrm{RNH}_{3}{ }^{+}, \mathrm{RNH}_{3}{ }^{+}$, and $\left(\mathrm{RNH}_{3}\right)_{2}{ }^{2+}$, so the electrostatic adsorption was strong between the two. Nevertheless, at $\mathrm{pH} 7.8-10$, the fluorite surface changed from positive to negative, i.e., the DDA adsorption capacity on the fluorite surface increased in a weak alkaline environment, which is in agreement with the flotation data that was obtained earlier. 


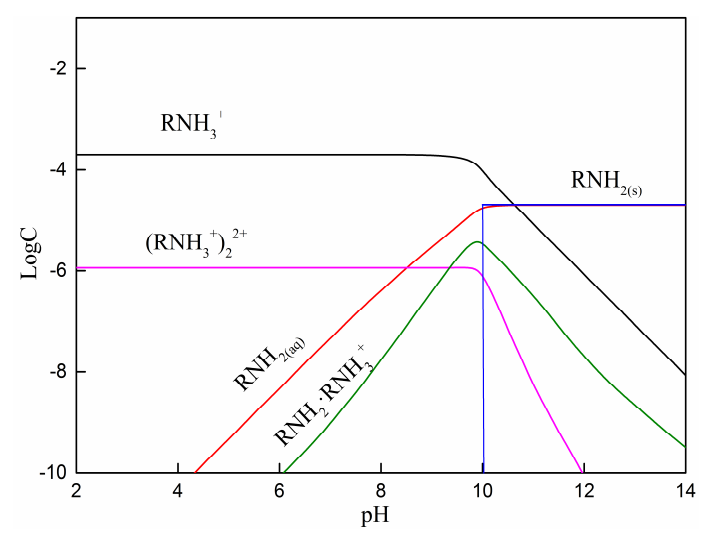

Figure 10. Species distribution diagram of DDA as a function of $\mathrm{pH}$. (DDA total conc. $=2.0 \times 10^{-4} \mathrm{~mol} / \mathrm{L}$.)

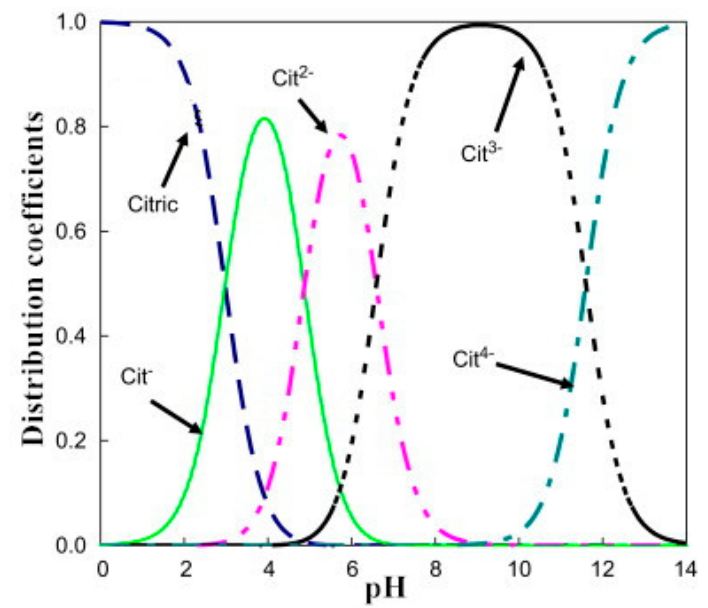

Figure 11. Species distribution diagram of $\mathrm{CA}$ as a function of $\mathrm{pH}\left(25^{\circ} \mathrm{C}\right.$ and $\left.1 \mathrm{~atm}\right)$ [30].

As seen in Figure 11, the $\mathrm{Cit}^{3-}$ species reached a maximum at $\mathrm{pH}$ 9.9, showing consistency with the flotation behavior of fluorite. In a strongly alkaline medium, the main CA species was $\mathrm{Cit}^{3-}$ and they played a significant role in the inhibition of fluorite. Certain studies have shown that the reactions of $\mathrm{Ca}^{2+}$ and $\mathrm{Cit}^{3-}$ ions were thermodynamically favored at $\mathrm{pH}$ in the range 5.5-13.0 [31]. Thus, anionic $\mathrm{Cit}^{3-}$ was adsorbed onto the negatively charged fluorite surface at $\mathrm{pH}>$ IEP 7.8 via chemical adsorption process rather than electrostatic attraction. In addition, fluorite ZP showed a significant difference when treated with both CA and DDA. Compared to the ZP in the presence of CA alone, the ZP of fluorite in the presence of both CA and DDA shifted to a slightly more acidic value. We assumed that DDA was physically adsorbed onto the fluorite surface in a similar manner to the sericite surface. However, in a $\mathrm{pH}$ range from $2-11$, the $\mathrm{pH}$ of the fluorite surface treated by both CA and DDA changed to high alkaline values. Thus, the assumption was invalid. Furthermore, this result implied that Cit ions in the pulp suspension transferred to the fluorite surfaces as the hydrolysis progressed and that additional chelates could be formed.

\subsection{FTIR Results}

The above experiments and analyses demonstrated that the depressant CA and the collector DDA could be selectively adsorbed onto sericite and fluorite surfaces, but the adsorption mechanism remains unclear and needs to be elucidated. Here, we analyze the FTIR spectra of sericite and fluorite to study the possible adsorption mechanism.

Sericite has two clear characteristic peaks at 3628 and $1024 \mathrm{~cm}^{-1}$ (Figure 12a), which were associated with stretching vibration of the $\mathrm{Al}-\mathrm{OH}$ groups and the in-plane stretching 
of the Si-O-Si (Al) or Si (Al)-O groups, respectively [32]. The peaks at 2357 and $2360 \mathrm{~cm}^{-1}$ were ascribed to the $\mathrm{CO}_{2}$ impurities (exclusion). For the DDA spectrum, two peaks at 2918 and $2844 \mathrm{~cm}^{-1}$ were attributed to $-\mathrm{CH}$ stretching. Similarly, the peak appearing at $2364 \mathrm{~cm}^{-1}$ and having a shoulder at $2335 \mathrm{~cm}^{-1}$ was attributed to the stretching of $-\mathrm{CN}$ group $[33,34]$. The spectra obtained for sericite with DDA indicated that the $-\mathrm{CH}_{3}$ or $-\mathrm{CH}_{2}$ stretching bands appeared at 2847 and $2919 \mathrm{~cm}^{-1}$. Additional band shifts of DDA could not be used to determine the electrostatic adsorption of DDA onto the surface of sericite. Furthermore, compared to the FTIR spectrum of the sericite treated with DDA only, the sericite treated with both CA and DDA did not show any CA characteristic peak, which confirmed the absence of $\mathrm{CA}$ absorption onto the sericite surface.

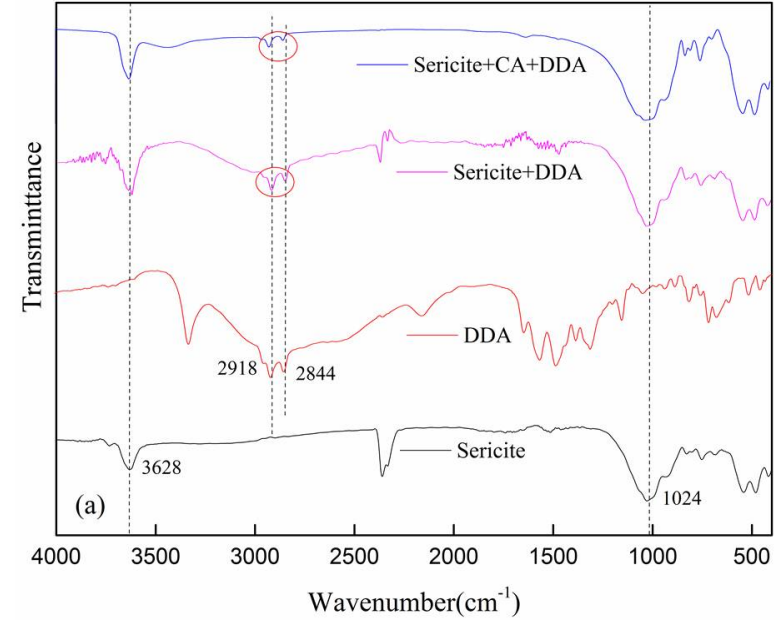

(a)

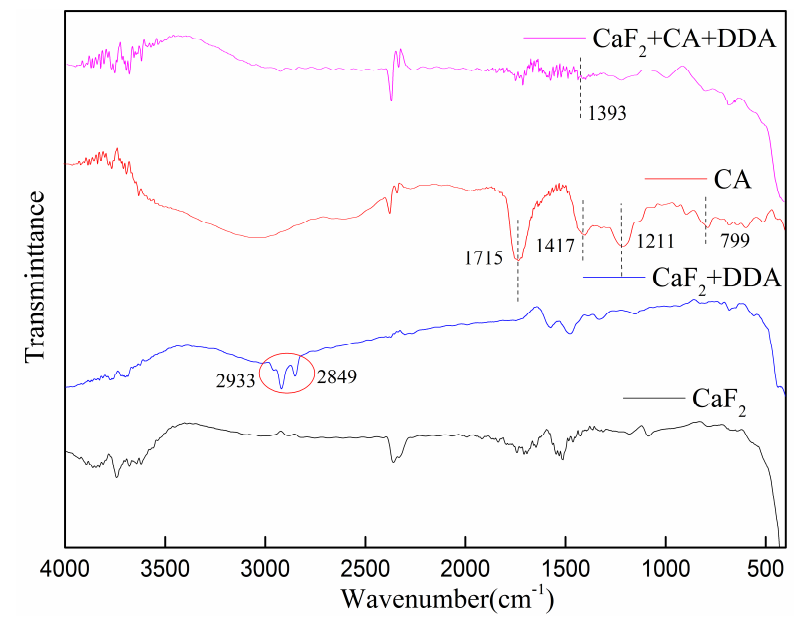

(b)

Figure 12. (a) Fourier transform infrared spectra of sericite pre- and post-binding with DDA and CA. (b) Fourier transform infrared spectra of fluorite pre- and post-binding with DDA and CA.

For the fluorite system, as shown in Figure 12b, similar peaks $\left(2933\right.$ and $2849 \mathrm{~cm}^{-1}$ ) appeared for the fluorite surface with DDA. This suggested the occurrence of an electrostatic adsorption process similar to that of sericite with DDA, and this in turn indicated that the selectivity of DDA was poor. In the FTIR spectrum of CA, the peaks observed at 1715, 3370, 1417 , and $799 \mathrm{~cm}^{-1}$ were due to the presence of $-\mathrm{COOH}$ groups, $-\mathrm{OH}$ groups, $\mathrm{C}-\mathrm{O}$ groups, and $\mathrm{C}-\mathrm{H}$ stretching, respectively. In comparison with the FTIR spectrum of the purified fluorite, the fluorite exposed to DDA and CA showed characteristic absorption peaks at 1715 and $3370 \mathrm{~cm}^{-1}$ owing to the presence of $-\mathrm{COOH}$ groups and weakened vibrations of $-\mathrm{OH}$ groups, respectively. Moreover, the peak at $1393 \mathrm{~cm}^{-1}$, caused by $\mathrm{C}-\mathrm{O}$ groups, represented a band shift of $24 \mathrm{~cm}^{-1}$ and demonstrated the chemisorption of CA on the fluorite surface. In the spectrum, fluorite treated with CA and DDA showed the change in characteristic absorption peaks as well as presented the symmetrical stretching vibration of chelates in the range $1500-1700 \mathrm{~cm}^{-1}$. Because of the disappearance of the stretching vibration of $-\mathrm{CH}$ groups (2933 and $2849 \mathrm{~cm}^{-1}$ ), we deduced that the DDA adsorption was hindered by the CA chemisorbed onto the fluorite surface.

\subsection{Batch Flotation Experiment Results}

Based on the optimized micro-flotation test conditions, two tests were conducted on a fluorite concentrate containing $92.87 \% \mathrm{CaF}_{2}$ (fluorite), $2.82 \% \mathrm{SiO}_{2}$ (sericite including $1.17 \%$ $\mathrm{Al}_{2} \mathrm{O}_{3}$ ), and $3.14 \% \mathrm{CaCO}_{3}$ (calcite), which was procured from the Xinyuan mine (Hunan, China). Most of the fluorite and sericite minerals in the fluorite powder were distributed in the $+10-37 \mu \mathrm{m}$ range. Fewer amounts as sericite were set in a fluorite combination $(10 \mu \mathrm{m})$. The images of the feed powders obtained via an optical microscope are shown in Figure 13. 

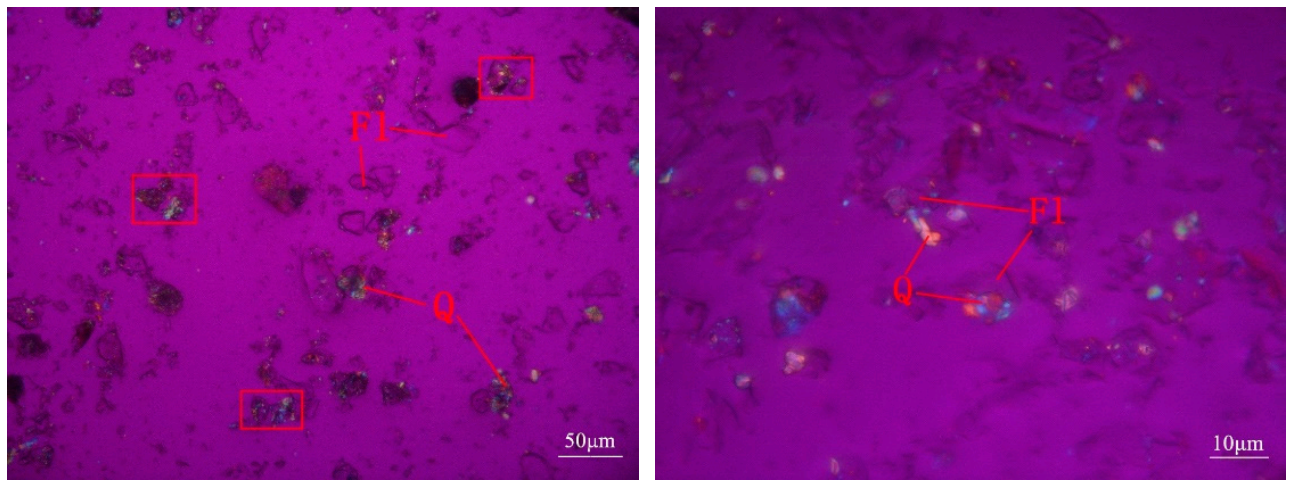

Figure 13. Images of feed material by microscope (F1—fluorite; Q—sericite).

As depicted in Figure 13, the average size of fluorite was clearly less than that of sericite. Additionally, at $10 \mu \mathrm{m}$, the sericite was present with the fluorite. Thus, it is difficult to further enrich the fluorite concentrate because the fine particles of sericite could be easily entrained [35] and $\mathrm{Ca}^{2+}$ ions could be activated by $\mathrm{NaOl}$ [27]. The detailed flowsheet and reagent scheme of the closed-circuit flotation are shown in Figure 3. The conditions for the comparison tests of flotation and the obtained results are represented in Table 1 and Figure 14, respectively.

Table 1. The conditions for the comparison tests of flotation.

\begin{tabular}{cc}
\hline Sample & Condition \\
\hline 1 & Fluorite concentrate \\
2 & Direct flotation (unwashed ore) $+\mathrm{SS}(200 \mathrm{~g} / \mathrm{t})+\mathrm{NaOl}(50 \mathrm{~g} / \mathrm{t})$ \\
3 & Direct flotation (washed ore) $+\mathrm{SS}(200 \mathrm{~g} / \mathrm{t})+\mathrm{NaOl}(50 \mathrm{~g} / \mathrm{t})$ \\
4 & Reverse flotation (unwashed ore $)+\mathrm{CA}(5 \mathrm{~kg} / \mathrm{t})+\mathrm{DDA}(50 \mathrm{~g} / \mathrm{t})$ \\
5 & Reverse flotation (washed ore $)+\mathrm{CA}(5 \mathrm{~kg} / \mathrm{t})+\mathrm{DDA}(50 \mathrm{~g} / \mathrm{t})$ \\
\hline
\end{tabular}

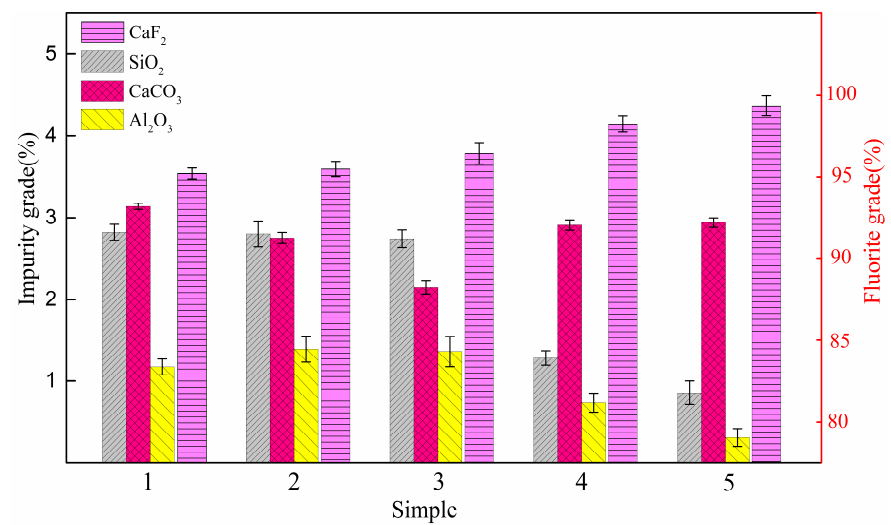

Figure 14. Results of the comparison tests of flotation (direct and reverse).

Figure 14 displays the results of the comparison tests of direct flotation and reverse flotation. Simple 1 was the fluorite concentrate and was retrieved from the flotation plant site. The unwashed simple 2 was treated with sodium silicate (SS). The $\mathrm{CaF}_{2}$ content of the concentrate increased slightly, but the $\mathrm{SiO}_{2}$ content showed no such changes. The $\mathrm{CaCO}_{3}$ content of the concentrate decreased when the fluorite concentrate was washed (simple 3), largely due to the inhibition of the impurity minerals caused by washing. However, the $\mathrm{SiO}_{2}$ and $\mathrm{Al}_{2} \mathrm{O}_{3}$ contents were unaffected. This proved that sericite could not be removed easily by direct flotation. When the CA and DDA dosages were $5.0 \mathrm{~kg} / \mathrm{t}$ and $50 \mathrm{~g} / \mathrm{t}$, respectively, fluorite content increased to $95.07 \%$, whereas $\mathrm{SiO}_{2}$ and $\mathrm{Al}_{2} \mathrm{O}_{3}$ content decreased from 2.82 to $1.28 \%$ and from 1.17 to $0.74 \%$, respectively. For comparison, to 
acquire the flotation performance via CA + DDA for cleaned samples, it was found that the residual reagent $(\mathrm{NaOl})$ used in the production and for the activation of sericite affected the collection of DDA. When simple 5 was cleaned, the $\mathrm{CaF}_{2}$ content of the concentrate increased to $95.89 \%$ and $\mathrm{SiO}_{2}$ recovery was only $30.49 \%$. Both $\mathrm{SiO}_{2}$ and $\mathrm{Al}_{2} \mathrm{O}_{3}$ content dropped. The root cause of this phenomenon was the ratio of $\mathrm{SiO}_{2}$ to $\mathrm{Al}_{2} \mathrm{O}_{3}$ in sericite (2:1). Furthermore, the removal rate of sericite was $69.51 \%$. Therefore, the reverse flotation of CA + DDA showed great potential for industrial applications. Owing to the volatility of the samples in batch flotation experiments, the grade and recovery of fluorite products were verified by subsequent semi-industrial tests.

\subsection{Pilot Test Results}

The process of the pilot test is illustrated in Figure 4. The primary purpose of the pilot test was to verify the feasibility of the batch flotation experiments. The results of the comparison tests for the direct leaching (process 1 plan date: May 10-17) and the reverse flotation + leaching (process 2 plan date: May 15-21) processes are depicted in Figure 15, Figure 16, and Figure 17. Figure 15 presents a comparison of the grade of fluorite concentrates obtained in processes 1 and 2 . The grade of fluorite in process 2 was $\sim 1.5 \%$ higher than that obtained in process 1 . According to the current market conditions, the price of fluorite powder $\left(\mathrm{CaF}_{2} \geq 97 \%\right)$ per ton is USD 39.67 higher than the original price of fluorite powder $\left(95 \% \leq \mathrm{CaF}_{2}<97 \%\right)$. Moreover, the $\mathrm{SiO}_{2}$ content of the concentrate in process 2 was $\sim 1.0 \%$ lower than that in process 1 (Figure 16). This result also contributed to the reduction in the consumption of sulfuric acid in the downstream hydrofluoric acid process and reduced the impurities in the product. In addition, the recovery of fluorite concentrate was lowered from 76.84 to $73.59 \%$ only, so the loss of fluorite is extremely small. Although the results of the pilot test have certain limitations, the new reverse flotation + leaching technology can dramatically reduce the potential costs and environmental impact. The new process not only contributed to the safety of AHF production plants but also reported a huge increase in the forecasted profits ( USD 1,4374.06 per day) (Table 2). Naturally, the economic benefits would also significantly improve with the increased price of high-grade fluorite powder $\left(\mathrm{CaF}_{2} \geq 97 \%\right)$.

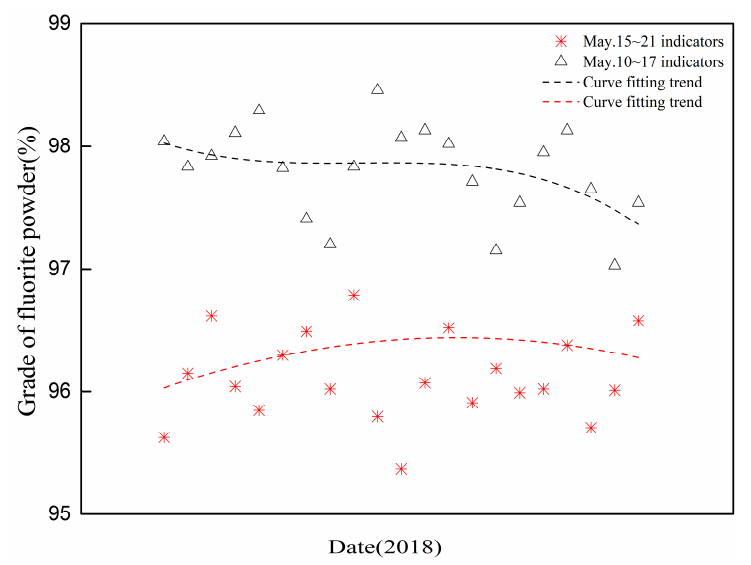

Figure 15. Comparison of the grade of fluorite concentrates in processes 1 and 2. 


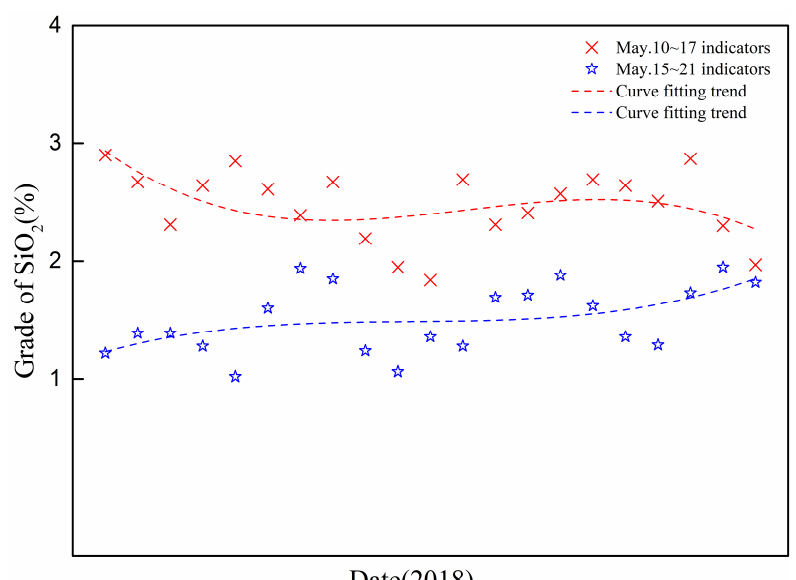

Figure 16. Comparison of the $\mathrm{SiO}_{2}$ content of the concentrates in processes 1 and 2.

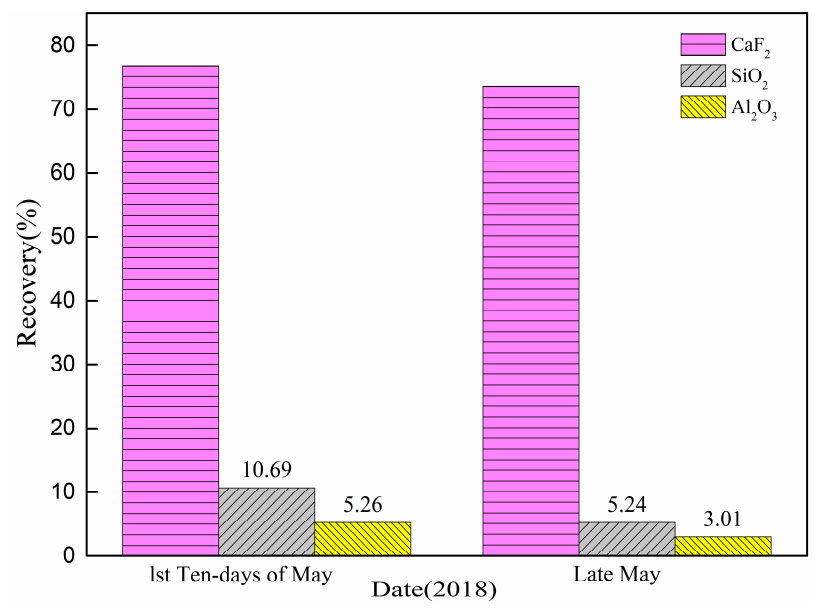

Figure 17. Results of mineral recovery from the fluorite concentrate in processes 1 and 2.

Table 2. Forecast profits based on pilot test results (2000 t/d).

\begin{tabular}{ccccc}
\hline Consumption & Unit Price (USD/t) & 1\# (t/d) & 2\# (t/d) & $\Delta$ Profit (USD/d) \\
\hline Fluorite powder $\left(95 \leq \mathrm{CaF}_{2}<97 \%\right)$ & 154.04 & 614.72 & $/$ & $+17,583.32$ \\
Fluorite powder $\left(\mathrm{CaF}_{2} \geq 97 \%\right)$ & 190.71 & $/$ & 588.72 & +1442.94 \\
Diluted hydrochloric & 58.68 & 73.77 & 49.18 & -4401 \\
Citric acid & 440.1 & $/$ & 10 & -337.41 \\
Dodecylamine & 3374.1 & $/$ & 0.1 & +76.29 \\
Waste water treatment cost & 2.934 & 1803.59 & 1727.30 & +9.92 \\
Power & 0.3814 & 234.45 & 224.53 & $+14,374.06$ \\
Total & $/$ & $/$ & $/$ & \\
\hline
\end{tabular}

\section{Conclusions}

This study found that reverse flotation was an efficient approach for the desilication of fluorite concentrates. Through micro-flotation tests, it was confirmed that the fluorite and sericite separation under acidic conditions or with CA + DDA could be quite successful. Additionally, a dominant electrostatic attraction force was detected in the interaction of DDA with sericite and fluorite, and the mechanism of CA was confirmed by ZP measurements, solution chemistry analysis, and FTIR. Furthermore, we found that the content of $\mathrm{SiO}_{2}$ and $\mathrm{Al}_{2} \mathrm{O}_{3}$ decreased during the batch flotation experiment. The results of the pilot test proved that the new reverse flotation + leaching technology could dramatically reduce the potential environmental impact and costs, thereby significantly improving the economic benefits by satisfying the current demands of the market. 
Author Contributions: Formal analysis, C.Z.; investigation, J.G. and F.L.; methodology, Y.H.; resources, W.S. and Z.L.; writing-original draft, C.Z.; writing-review and editing, J.G. and C.Z.; project administration, W.S and Y.H. All authors have read and agreed to the published version of the manuscript.

Funding: This research was funded by the National Natural Science Foundation of Guizhou Province (qian ke he ji chu [2020]1Y218); the Young Talents Foundation of Education Department of Guizhou Province (qian jiao he KY zi [2019]136) and the Scientific and Technological Innovation Platform of Liupanshui (52020-2019-05-04 and 52020-2019-05-06); the Academician Workstation of Liupanshui Normal University (qiankehepingtairencai [2019]5604hao); the Fund of Liupanshui Normal University (LPSSYKJTD201906).

Data Availability Statement: Not applicable.

Conflicts of Interest: The authors declare no conflict of interest.

\section{References}

1. Zhang, Y.; Song, S. Beneficiation of fluorite by flotation in a new chemical scheme. Miner. Eng. 2003, 16, 597-600. [CrossRef]

2. Gao, Z.; Wang, C.; Sun, W.; Gao, Y.; Kowalczuk, P.B. Froth flotation of fluorite: A review. Adv. Colloid Interface Sci. 2021, 290, 102382. [CrossRef]

3. Shuai, F.; Xu, L.; Wu, H.; Jia, T.; Lu, Z.; Wei, S.; Hu, Y. Adsorption of $\mathrm{Pb}(\mathrm{II})$ /benzohydroxamic acid collector complexes for ilmenite flotation. Miner. Eng. 2018, 126, 16-23. [CrossRef]

4. Gao, Y.; Gao, Z.; Sun, W.; Hu, Y. Selective flotation of scheelite from calcite: A novel reagent scheme. Int. J. Miner. Process. 2016, 154, 10-15. [CrossRef]

5. Kou, J.; Tao, D.; Xu, G. Fatty acid collectors for phosphate flotation and their adsorption behavior using QCM-D. Int. J. Miner. Process. 2010, 95, 1-9. [CrossRef]

6. Hu, Y.-H.; Yang, F.; Sun, W. The flotation separation of scheelite from calcite using a quaternary ammonium salt as collector. Miner. Eng. 2011, 24, 82-84. [CrossRef]

7. Liu, C.; Zhou, M.; Xia, L.; Fu, W.; Zhou, W.; Yang, S. The utilization of citric acid as a depressant for the flotation separation of barite from fluorite. Miner. Eng. 2020, 156, 106491. [CrossRef]

8. Filippov, L.; Filippova, I.; Severov, V. The use of collectors mixture in the reverse cationic flotation of magnetite ore: The role of Fe-bearing silicates. Miner. Eng. 2010, 23, 91-98. [CrossRef]

9. Ma, X.; Marques, M.; Gontijo, C. Comparative studies of reverse cationic/anionic flotation of Vale iron ore. Int. J. Miner. Process. 2011, 100, 179-183. [CrossRef]

10. Santos, E.P.; Dutra, A.J.; Oliveira, J.F. The effect of jojoba oil on the surface properties of calcite and apatite aiming at their selective flotation. Int. J. Miner. Process. 2015, 143, 34-38. [CrossRef]

11. Liu, H.; Khoso, S.A.; Sun, W.; Zhu, Y.; Han, H.; Hu, Y.; Kang, J.; Meng, X.; Zhang, Q. A novel method for desulfurization and purification of fluorite concentrate using acid leaching and reverse flotation of sulfide. J. Clean. Prod. 2019, 209, 1006-1015. [CrossRef]

12. Zhang, C.; Sun, W.; Hu, Y.; Tang, H.; Yin, Z.; Guan, Q.; Gao, J. Investigation of two-stage depressing by using hydrophilic polymer to improve the process of fluorite flotation. J. Clean. Prod. 2018, 193, 228-235. [CrossRef]

13. Mowla, D.; Karimi, G.; Ostadnezhad, K. Removal of hematite from silica sand ore by reverse flotation technique. Sep. Purif. Technol. 2008, 58, 419-423. [CrossRef]

14. Mohammadkhani, M.; Noaparast, M.; Shafaei, S.; Amini, A.; Amini, E.; Abdollahi, H. Double reverse flotation of a very low grade sedimentary phosphate rock, rich in carbonate and silicate. Int. J. Miner. Process. 2011, 100, 157-165. [CrossRef]

15. Yang, S.; Xu, Y.; Liu, C.; Huang, L.; Huang, Z.; Li, H. The anionic flotation of fluorite from barite using gelatinized starch as the depressant. Colloids Surfaces A Physicochem. Eng. Asp. 2020, 597, 124794. [CrossRef]

16. Lin, L.; Jiong-tian, L.; Yong-tian, W.; Yi-jun, C.; Hai-jun, Z.; He-sheng, Y. Experimental research on anionic reverse flotation of hematite with a flotation column. Procedia Earth Planet. Sci. 2009, 1, 791-798. [CrossRef]

17. Abaka-Wood, G.B.; Addai-Mensah, J.; Skinner, W. A study of flotation characteristics of monazite, hematite, and quartz using anionic collectors. Int. J. Miner. Process. 2017, 158, 55-62. [CrossRef]

18. Liu, G.; Zhong, H.; Hu, Y.; Zhao, S.; Xia, L. The role of cationic polyacrylamide in the reverse flotation of diasporic bauxite. Miner Eng. 2007, 20, 1191-1199. [CrossRef]

19. Xu, L.; Longhua, X.; Tian, J.; Wu, H.; Wang, L.; Yang, Y.; Wang, Z. Synergistic effect of mixed cationic/anionic collectors on flotation and adsorption of muscovite. Colloids Surfaces A Physicochem. Eng. Asp. 2016, 492, 181-189. [CrossRef]

20. Wang, L.; Hu, Y.; Liu, J.; Sun, Y.; Sun, W. Flotation and adsorption of muscovite using mixed cationic-nonionic surfactants as collector. Powder Technol. 2015, 276, 26-33. [CrossRef]

21. Sahoo, H.; Rath, S.S.; Das, B.; Mishra, B.K. Flotation of quartz using ionic liquid collectors with different functional groups and varying chain lengths. Miner. Eng. 2016, 95, 107-112. [CrossRef] 
22. Lima, N.P.; Valadão, G.E.; Peres, A.E. Effect of amine and starch dosages on the reverse cationic flotation of an iron ore. Miner. Eng. 2013, 45, 180-184. [CrossRef]

23. Liu, Q.; Zhang, Y. Effect of calcium ions and citric acid on the flotation separation of chalcopyrite from galena using dextrin. Miner. Eng. 2000, 13, 1405-1416. [CrossRef]

24. Liu, C.; Zheng, Y.; Yang, S.; Fu, W.; Chen, X. Exploration of a novel depressant polyepoxysuccinic acid for the flotation sep-aration of pentlandite from lizardite slimes. Appl. Clay Sci. 2020, 105939. [CrossRef]

25. Gan, W.; Crozier, B.; Liu, Q. Effect of citric acid on inhibiting hexadecane-quartz coagulation in aqueous solutions containing $\mathrm{Ca}^{2+}, \mathrm{Mg}^{2+}$ and $\mathrm{Fe}^{3+}$ ions. Int. J. Miner. Process. 2009, 92, 84-91. [CrossRef]

26. Gao, Z.; Gao, Y.; Zhu, Y.; Hu, Y.; Sun, W. Selective Flotation of Calcite from Fluorite: A Novel Reagent Schedule. Minerals 2016, 6, 114. [CrossRef]

27. Hu, Y.; He, J.; Zhang, C.; Zhang, C.; Sun, W.; Zhao, D.; Chen, P.; Han, H.; Gao, Z.; Liu, R.; et al. Insights into the activation mechanism of calcium ions on the sericite surface: A combined experimental and computational study. Appl. Surf. Sci. 2018, 427, 162-168. [CrossRef]

28. Gao, Z.; Sun, W.; Hu, Y.-H.; Liu, X.-W. Anisotropic surface broken bond properties and wettability of calcite and fluorite crystals. Trans. Nonferrous Met. Soc. China 2012, 22, 1203-1208. [CrossRef]

29. Somasundaran, P.; Wang, D. Solution Chemistry: Minerals and Reagents; Elsevier: Amsterdam, The Netherlands, 2006; ISBN 0080465072.

30. Al-Khaldi, M.; Nasr-El-Din, H.; Mehta, S.; Al-Aamri, A. Reaction of citric acid with calcite. Chem. Eng. Sci. 2007, 62, 5880-5896. [CrossRef]

31. Nagy, N.M.; Konya, J.; Kónya, I. Ion-exchange processes of lead and cobalt ions on the surface of calcium-montmorillonite in the presence of complex-forming agents II. The effect of DTPA, tartaric acid and citric acid on the sorption of lead ions on calcium-montmorillonite. Colloids Surfaces A Physicochem. Eng. Asp. 1998, 137, 243-252. [CrossRef]

32. Tian, J.; Gao, H.; Guan, J.; Ren, Z. Modified floc-flotation in fine sericite flotation using polymethylhydrosiloxane. Sep. Purif. Technol. 2017, 174, 439-444. [CrossRef]

33. Carrara, C.; Irusta, S.; Lombardo, E.; Cornaglia, L. Study of the Co-VPO interaction in promoted n-butane oxidation catalysts. Appl. Catal. A Gen. 2001, 217, 275-286. [CrossRef]

34. Gupta, N.; Balomajumder, C.; Agarwal, V.K. Adsorption of cyanide ion on pressmud surface: A modeling approach. Chem. Eng. J. 2012, 191, 548-556. [CrossRef]

35. Warren, L.J. Determination of the contributions of true flotation and entrainment in batch flotation tests. Int. J. Miner. Process. 1985, 14, 33-44. [CrossRef] 